\title{
ANALISIS KINERJA KEUANGAN KOPERASI "SINAR HARAPAN" STKIP YPM BANGKO DI KABUPATEN MERANGIN JAMBI
}

\author{
Kusaimah \\ STKIP YPM Bangko \\ email: kusaimahsai@gmail.com
}

\begin{abstract}
Penelitian ini bertujuan untuk menganalisis kinerja keuangan koperasi karyawan "Sinar Harapan" STKIP YPM Bangko. Penelitian ini digolongkan sebagai penelitian deskriptif dengan objek penelitian yaitu laporan keuangan koperasi "Sinar Harapan” dalam kurun waktu 2011-2015.

Hasil penelitian menunjukkan bahwa analisis likuiditas pada koperasi Sinar Harapan dilihat berdasarkan angka rasio yang dihasilkan menunjukkan angka yang cukup baik atau likuid pada analisis Current Ratio yaitu dengan angka sesuai standar (200\%). Analisis Laverage pada koperasi Sinar Harapan menunjukkan hasil yang sangat baik atau solvable dalam memenuhi kewajibankewajiban panjang maupun pendeknya. Analisis ROA (Return on Assets) dan ROE (Return On Equity) menunjukkan bahwa kinerja manajemen koperasi sangat baik dalam menghasilkan SHU yang maksimal. Analisis aktivitas menunjukkan tingkat perputaran asset ataupun modal kerja memberikan turn over yang rendah terhadap perolehan pendapatan.
\end{abstract}

Keywords: Kinerja Keuangan, Rasio Likuiditas, Rasio Laverage, Rasio Aktivitas, Rasio Profitabilitas.

\section{PENDAHULUAN}

Struktur perekonomian Indonesia membagi kegiatan ekonomi menjadi tiga (3) kelompok badan usaha, yaitu Badan Usaha Milik Negara (BUMN), koperasi dan Badan Usaha Milik Swasta (BUMS). Dari ketiga kekuatan ekonomi nasional tersebut pemerintah mengharapkan agar dikembangkan menjadi komponenkomponen yang saling mendukung dan terpadu di dalam sistem ekonomi nasional. Sesuai dengan pasal 33 ayat 1 Undang Undang Dasar 1945, bahwa koperasi adalah merupakan salah satu pelaku ekonomi yang disusun dan dijalankan sebagai usaha bersama dari anggota dan untuk kesejahteraan seluruh anggota.

Koperasi merupakan salah satu kekuatan ekonomi yang tumbuh di kalangan masyarakat sebagai pendorong tumbuhnya perekonomian nasional sekaligus sebagai soko guru dalam perekonomian di Negara Indonesia. Menurut UU No.25 Tahun 1992 tentang perkoperasian BABI Pasal 1 Koperasi adalah" Badan usaha yang beranggotakan orang seorang atau badan hukum koperasi dengan melandaskan kegiatannya berdasarkan prinsip koperasi sebagai gerakan ekonomi rakyat yang berdasarkan atas azas kekeluargaan".

Saat ini banyak bermunculan koperasikoperasi baru, baik yang sudah mandiri maupun yang belum mandiri, sehingga mengakibatkan persaingan dalam rangka mengembangkan usahanya. Untuk mengantisipasi persaingan antar koperasi maupun badan usaha lainnya, diperlukan suatu sistem pengolahan dan manajemen koperasi yang baik.Unit usaha koperasi "Sinar Harapan" STKIP YPM Bangko merupakan salah satu koperasi yang dimiliki oleh seluruh karyawan STKIP YPM Bangko.

Koperasi Sinar Harapan bergerak dalam bidang koperasi simpan pinjam. Dalam menjalankan aktivitasnya koperasi Sinar Harapan ini dijalankan oleh manajemen yang terpilih secara demokratis. 
Manajemen yang mampu menggunakan sumber daya secara efektif dan efisien merupakan usaha untuk mendukung peningkatan pengelolaan koperasi yang membutuhkan analisis terhadap laporan keuangan. Aspek keuangan sebagai salah satu sumber daya strategis untuk menjalankan usaha kelangsungan hidup koperasi. Selain itu dapat menentukan berbagai kemungkinan perolehan sumber dana dengan biaya relatif murah, serta untuk membiayai berbagai kegiatan sesuai dengan prioritas yang telah ditentukan.

Konsep analisis rasio merupakan suatu alat untuk mengukur apakah unit usaha tersebut likuid dalam menjalankan usahanya. Analisis laporan keuangan suatu perusahaan atau badan usaha lain dilakukan sesuai dengan kondisi perusahaan atau badan usaha lain tersebut, karena tidak semua analisis laporan keuangan dapat diterapkan pada semua perusahaan atau badan usaha lain. Alat analisis rasionya ada tiga (3), yaitu: rasio likuiditas, rasio leverage, rasio profitabilitas.

Rasio likuditas memperlihatkan kemampuan perusahaan dalam membiayai kegiatan operasional serta melunasi hutang jangka pendeknya. Banyaknya metode yang digunakan untuk mengukur tingkat likuditas kinerja keuangan seperti Current ratio, Quick Ratio dan Cash Ratio. Sedangkan rasio leverage atau rasio solvabilitas merupakan rasio yang digunakan untuk menganalisis kemmapuan perusahaan untuk melunasi seluruh kewajibannya pada saat dilikuidasi. Rasio yang digunakan untuk menganalisis rasio leverage seperti Total Debt To Equity Ratio, Total Debt To Capital Assets, Debt Ratio, Time Interest Earned Ratio dan cash coverage ratio. Tidak hanya sekedar rasio likuditas dan rasio leverage, analisis yang selanjutnya yang tidak kalah penting adalah analisis rasio profitabilitas yang merupakan analisis untuk mengukur tingkat kemampuan suatu badan usaha dalam menciptakan laba. Analisis ini bisa menggunakan Gross Profit Margin,
Operating Profit Margin, Net Profit Margin, Return On Investment, Return On Equity, dan Return On Assets.

Berdasarkan hasil pengamatan yang dilakukan pada Koperasi Karyawan Sinar Harapan, dijumpai bahwa kinerja keuangan pada koperasi tersebut secara keseluruhan belum efektif dan efisien dikarenakan tingkat fluktuasi dari pada aktiva dan laba usaha yang terjadi. Secara umum kinerja Koperasi Karyawan Sinar Harapan meliputi pelayanan kepada anggota, manajemen keuangan, pengendalian atau sistem kontrol yang sifatnya terus-menerus. Sedangkan secara khusus kinerja keuangan memfokuskan kepada bagaimana mengelola keuangan organisasi dengan sebaik-baiknya demi mendatangan keuntungan yang optimal. Dalam hal ini, maka pengelolaan keuangan tersebut harus seimbang antara pendapatan dan belanja, namun koperasi karyawan Sinar Harapan belum sepenuhnya melaksanakan analisis laporan keuangan sehingga kinerja dari pihak manajemen koperasi belum mampu sepenuhnya dinilai. Ketidakadaan analisis keuangan ini membuat pihak manajemen belum mampu melakukan evaluasi terhadap aktivitas operasi koperasi apakah sudah berjalan secara efektif atau belum.

Berdasarkan pengamatan peneliti lebih lanjut tentang laporan keuangan yang ada pada Koperasi Karyawan "Sinar Harapan" STKIP YPM Bangko. Peneliti hanya menemukan laporan keuangan sederhana yaitu berupa laporan SHU dan laporan neraca dan tergambar pada tabel di bawah ini:

\begin{tabular}{|c|c|c|c|c|}
\hline $\begin{array}{c}\text { Indikator/ } \\
\text { Tahun }\end{array}$ & $\begin{array}{c}\text { Pasiva+ } \\
\text { Modal }\end{array}$ & SHU Bruto & $\begin{array}{c}\text { SHU } \\
\text { Bersih }\end{array}$ & Modal \\
\hline 2011 & 194.703 .500 & 19.743 .700 & 16.166 .263 & 135.077 .036 \\
\hline 2012 & 214.703 .500 & 29.512 .500 & 25.737 .375 & 142.648 .148 \\
\hline 2013 & 225.693 .333 & 30.692 .880 & 29.826 .208 & 158.437 .981 \\
\hline 2014 & 241.187 .352 & 33.896 .170 & 34.252 .000 & 148.787 .000 \\
\hline 2015 & 245.387 .352 & 38.344 .920 & 40.152 .000 & 177.187 .000 \\
\hline
\end{tabular}

Tabel.1.1 Laporan perkembangan

Keuangan Koperasi Karyawan Sinar Harapan STKIP Bangko Tahun 2010-2014

Pada Tabel 1.1. menunjukkan bahwa laporan keuangan belum mampu 
menunjukkan kinerja keuangan Koperasi Karyawan "Sinar Harapan" STKIP YPM Bangko. Laporan keuangan yang ada hanya menunjukkan tentang jumlah modal serta perolehan SHU. Pihak manajemen Koperasi Karyawan "Sinar Harapan" STKIP YPM Bangko belum pernah melaksanakan analisis laporan keuangan. Hal ini tentu saja belum mampu menunjukkan kinerja pihak manajemen dalam menjalankan operasional koperasi tersebut. Angka yang ditunjukkan oleh SHU juga belum menggambarkan ROA dan ROE. Dimana analisis terhadap ROA dan ROE menjadi salah satu indikator bagi anggota untuk memilih apakah ingin tetap bergabung ataupun tidak pada Koperasi Karyawan "Sinar Harapan" STKIP YPM Bangko.

Fokus penelitan hanya analisis kinerja keuangan koperasi karyawan STKIP YPM Bangko saja.

\section{METODE PENELITIAN}

Penelitian ini digolongkan sebagai penelitian deskriptif yaitu penelitian yang dilakukan dengan menggunakan data primer dan menjelaskan bagaimana kinerja keuangan koperasi serta standar kriteria keuangan sebagai koperasi mandiri yang ditetapkan oleh KeputusanMenteri Negara Koperasidan

UKM

No.129/Kep/M/KUKM/XI/2003-2004.

Penelitian ini merupakan penelitian deskriptif yang menjelaskan bagaimana tingkat likuiditas, leverage dan profitabilitasserta aktivitas operasi Koperasi Karyawan "Sinar Harapan" STKIP YPM Bangko dengan berdasarkan hasil perhitungan rasio keuangan. Penelitian ini menggunakan laporan keuangan berupa laporan keuangan neraca dan laporan sisa hasil usaha.

Penelitian ini mengacu kepada analisis laporan keuangan koperasi karyawan "“ Sinar Harapan" dalam kurun waktu 20112015.

\section{HASIL DAN PEMBAHASAN}

\section{A. Analisis Rasio Likuiditas}

Analisis likuiditas merupakan kemampuan koperasi untuk memenuhi kewajiban jangka pendeknya. Pemenuhan kewajiban jangka pendek suatu lembaga dapat dijaminkan dengan jumlah aktiva yang dimilki koperasi

\section{a. Current Rasio}

Rasio ini menunjukkan sampai dimana hutang-hutang jangka pendek dapat dibayar dari aktiva-aktiva yang dapat dijadikan uang pada waktu yang sama misal, jangka waktu pembayaran hutang-hutang jangka pendek. Secara umum rasio ini bisa dikatakan baik, jika nilainya mencapai 2 atau $200 \%$.

\begin{tabular}{|c|c|c|c|}
\hline Komponen & Standar & Nilai & Kriteria \\
\hline Rasio & $175 \%-200 \%$ & 100 & Sangat Baik \\
Likuiditas & $150 \%-174 \%$ & 75 & Baik \\
CurrentRatio & $125 \%-149 \%$ & 50 & Kurang Baik \\
& $100 \%-125 \%$ & 25 & Buruk \\
& $<100 \%$ & 0 & \\
\hline
\end{tabular}

Tabel2.1 Standar Perhitungan CurrentRatio Dari penggunaan rumus di atas untuk perhitungan analisis current ratio atas laporan keuanagan koperasi Sinar Harapan maka diperoleh hasilnya sesuai yang ditampilkan pada tabel 2.2 di bawah ini:

\begin{tabular}{|c|c|c|c|c|c|}
\hline Tahun & $\begin{array}{c}\text { Total } \\
\text { Aktiva } \\
\text { Lancar (Rp) }\end{array}$ & $\begin{array}{c}\text { Total } \\
\text { Lutang } \\
(\mathrm{Rp})\end{array}$ & $\begin{array}{c}\text { Rasio } \\
(\%)\end{array}$ & Nilai & Kriteria \\
\hline 2011 & 174.903 .500 & 59.626 .464 & 293,332 & 100 & $\begin{array}{c}\text { Sangat } \\
\text { Baik }\end{array}$ \\
\hline 2012 & 195.003 .500 & 72.055 .352 & 270,630 & 100 & $\begin{array}{c}\text { Sangat } \\
\text { Baik }\end{array}$ \\
\hline 2013 & 206.093 .333 & 67.255 .352 & 306,434 & 100 & $\begin{array}{c}\text { Sangat } \\
\text { Baik }\end{array}$ \\
\hline 2014 & 221.687 .352 & 92.400 .352 & 239,920 & 100 & $\begin{array}{c}\text { Sangat } \\
\text { Baik }\end{array}$ \\
\hline 2015 & 225.987 .352 & 68.200 .352 & 331,358 & 100 & $\begin{array}{c}\text { Sangat } \\
\text { Baik }\end{array}$ \\
\hline
\end{tabular}

Tabel2.2 Daftar Perhitungan Analisis

Current Rasio Tahun 2011-2015

\section{b. Cash Ratio}

Cash rasio menujukkan hubungan antara perbandingan kas dan setara kas dengan hutang lancar yang dimiliki oleh koperasi. Rasio ini digunakan untuk mengukur kemampuan kas yang sesungguhnya untuk memenuhi hutang-hutangnya tepat pada waktunya.

\begin{tabular}{|l|l|l|l|}
\hline Komponen & Standar & Nilai & Kriteria \\
\hline
\end{tabular}




\begin{tabular}{|c|c|c|c|}
\hline CashRatio & $175 \%-200 \%$ & 100 & Sangat Baik \\
& $150 \%-174 \%$ & 75 & Baik \\
& $125 \%-149 \%$ & 50 & Kurang Baik \\
& $100 \%-125 \%$ & 25 & Buruk \\
& $<100 \%$ & 0 & \\
\hline
\end{tabular}

Tabel2.3 Standar Perhitungan CashRatio

\section{B. Analisis Rasio Leverage}

Solvabilitas adalah menunjukkan kemampuan koperasi untuk memenuhi kewajiban keuangan jangka pendek maupun jangka panjang. Perusahaan disebut solvableapabila koperasi mempunyai aktiva atau kekayaan yang cukup untuk membayar semua hutanghutangnya. Sedangkan koperasi yang tidak mempunyai aktiva atau kekayaan yang cukup untuk membayar semua hutanghutangnya disebutinsolvabel. Yang termasuk Rasio Solvabilitas, antaralain:

\section{a. Total Debt to Total asset}

Rasioini membandingkan jumlah total utang dengan aktiva total yang dimiliki perusahaan. Dari rasio inidapat diketahui beberapa bagian aktiva yang gunakan untuk menjamin utang.

\begin{tabular}{|c|c|c|c|}
\hline Komponen & Standar & Nilai & Kriteria \\
\hline Leverage & $<40 \%$ & 100 & Sangat Baik \\
Rasio Total & $50 \%-39 \%$ & 75 & Baik \\
Hutang & $60 \%-49 \%$ & 50 & Kurang Baik \\
Degan Total & $80 \%-59 \%$ & 25 & Buruk \\
Aktiva & $>80 \%$ & 0 & \\
\hline
\end{tabular}

Table2.4Standar Perhitungan Rasio TH denganTA(sumber:KementrianKoperasida $n U K M R I 2004)$.

Dari penggunan rumus di atas terhadap laporan keuangan koperasi Sinar Harapan, hasilnya dapat ditunjukkan pada tabel 4.6 di bawah ini

\begin{tabular}{|c|c|c|c|c|c|}
\hline Tahun & $\begin{array}{c}\text { Total } \\
\text { Hutang } \\
(\mathbf{R p})\end{array}$ & $\begin{array}{c}\text { Total } \\
\text { Aktiva } \\
(\mathbf{R p})\end{array}$ & $\begin{array}{c}\text { Rasio } \\
(\boldsymbol{\%})\end{array}$ & Nilai & Kriteria \\
\hline 2011 & 59.626 .464 & 194.703 .500 & 30,624 & 100 & $\begin{array}{c}\text { Sangat } \\
\text { Baik }\end{array}$ \\
\hline 2012 & 72.055 .352 & 214.703 .500 & 33,560 & 100 & $\begin{array}{c}\text { Sangat } \\
\text { Baik }\end{array}$ \\
\hline 2013 & 67.255 .352 & 225.693 .333 & 29,799 & 100 & $\begin{array}{c}\text { Sangat } \\
\text { Baik }\end{array}$ \\
\hline 2014 & 92.400 .352 & 241.187 .352 & 38,311 & 100 & $\begin{array}{c}\text { Sangat } \\
\text { Baik }\end{array}$ \\
\hline 2015 & 68.200 .352 & 245.387 .352 & 27,793 & 100 & $\begin{array}{c}\text { Sangat } \\
\text { Baik }\end{array}$ \\
\hline
\end{tabular}

Table 2.5Daftar Perhitungan Analsis Rasio Leverage Tahun 2011-2015

\section{b. Long Term to Equity Ratio}

Rasio ini membandingkan jumlah total utang dengan aktiva total yang dimiliki perusahaan. Dari rasio ini, dapat diketahui beberapa bagian aktiva yang digunakan untuk menjamin utang.

\begin{tabular}{|c|c|c|c|}
\hline Komponen & Standar & Nilai & Kriteria \\
\hline Solvabilitas & $<40 \%$ & 100 & Sangat Baik \\
Rasio Total & $50 \%-39 \%$ & 75 & Baik \\
Hutang & $60 \%-49 \%$ & 50 & Kurang Baik \\
Jangka & $80 \%-59 \%$ & 25 & Buruk \\
Panjang & $>80 \%$ & 0 & \\
\hline
\end{tabular}

Tabel 2.6 Standar Perhitungan Rasio Total Hutang jangka Panjang Dengan Modal sendiri.

\section{Analisis Rasio Profitabilitas}

Profitabilitas adalah menunjukkan kemampuan koperasi untuk menghasilkan Sisa Hasil Usaha dalam periopde tertentu. Rentabilitas koperasi diukur dari kesuksesan koperasi dan kemampuan menggunakan aktivanya secara produktif, dengan demikian rentabilitas suatu koperasi dapat diketahui dengan memperbandingkan antara Sisa Hasil Usaha yang diperoleh dalam suatu periode dengan jumlah aktiva atau jumlah modal koperasi tersebut.

Yang termasuk dalam Rasio Rentabilitas, yaitu:

\section{a. Return On Assets (ROA)}

Analisis ROAmengukur kemampuan perusahaan menghasilkan laba denga menggunakan total assets (kekayaan) yang dipunyai oleh perusahaan setelah disesuaikan dengan biaya-biaya untuk mendanai assets tersebut.

\begin{tabular}{|c|c|c|c|}
\hline Komponen & Standar & Nilai & Kriteria \\
\hline Rentabilitas & $>10 \%$ & 100 & Sangat Baik \\
ROA & $7 \%-10 \%$ & 75 & Baik \\
& $3 \%-6 \%$ & 50 & Kurang Baik \\
& $1 \%-2 \%$ & 25 & Buruk \\
& $<1 \%$ & 0 & \\
\hline
\end{tabular}

Table2.7 Standar Perhitungan ROA

Berdasarkan rumus perhitungan ROA di atas maka diperoleh analisis ratio atas ROA terhadap kinerja laporan keuangan koperasi Sinar Harapan yang ditunjukkan oleh Tabel: 


\begin{tabular}{|c|c|c|c|c|c|}
\hline Tahun & $\begin{array}{c}\text { SHU } \\
\text { Bersih }\end{array}$ & $\begin{array}{c}\text { Total } \\
\text { Aktiva }\end{array}$ & $\begin{array}{c}\text { Rasio } \\
(\%)\end{array}$ & Nilai & Kriteria \\
\hline 2011 & 16.166 .263 & 194.703 .500 & 8,303 & 75 & Baik \\
\hline 2012 & 25.737 .375 & 214.703 .500 & 11,987 & 100 & $\begin{array}{c}\text { Sangat } \\
\text { Baik }\end{array}$ \\
\hline 2013 & 29.827 .208 & 225.693 .333 & 13,216 & 100 & $\begin{array}{c}\text { Sangat } \\
\text { Baik }\end{array}$ \\
\hline 2014 & 34.252 .000 & 241.187 .352 & 14,201 & 100 & $\begin{array}{c}\text { Sangat } \\
\text { Baik }\end{array}$ \\
\hline 2015 & 40.152 .000 & 245.387 .352 & 16,363 & 100 & $\begin{array}{c}\text { Sangat } \\
\text { Baik }\end{array}$ \\
\hline
\end{tabular}

Table2.8 Daftar Perhitngan Analisis ROA

\section{b. Return On Equity (ROE)}

Return On Equity adalah rasio yang membandingkan antara Sisa Hasil Usaha dan jumlah modal sendiri. Rasio ini menunjukkan kemampuan modal dalam menghasilkan Sisa Hasil Usaha.

\begin{tabular}{|c|c|c|c|}
\hline Komponen & Standar & Nilai & Kriteria \\
\hline Rentabilitas & $>21 \%$ & 100 & Sangat Baik \\
ROE & $15 \%-20 \%$ & 75 & Baik \\
& $10 \%-14 \%$ & 50 & Kurang Baik \\
& $3 \%-9 \%$ & 25 & Buruk \\
& $<3 \%$ & 0 & \\
\hline
\end{tabular}

Tabel 2.9 Standar perhitungan Return On Equity

\begin{tabular}{|c|c|c|c|c|c|}
\hline Tahun & $\begin{array}{c}\text { SHU } \\
\text { Bersih }\end{array}$ & $\begin{array}{c}\text { Modal } \\
\text { Sendiri }\end{array}$ & $\begin{array}{c}\text { Rasio } \\
(\%)\end{array}$ & Nilai & Kriteria \\
\hline 2011 & 16.166 .263 & 135.077 .036 & 11,968 & 50 & $\begin{array}{c}\text { Cukup } \\
\text { Baik }\end{array}$ \\
\hline 2012 & 25.737 .375 & 142.648 .148 & 18,043 & 75 & Baik \\
\hline 2013 & 29.827 .208 & 158.437 .981 & 18,826 & 75 & Baik \\
\hline 2014 & 34.252 .000 & 148.787 .000 & 23,021 & 100 & $\begin{array}{c}\text { Sangat } \\
\text { Baik }\end{array}$ \\
\hline 2015 & 40.152 .000 & 177.187 .000 & 22,661 & 100 & $\begin{array}{c}\text { Sangat } \\
\text { Baik }\end{array}$ \\
\hline
\end{tabular}

\section{Analisis Aktivitas}

Rasio ini melihat pada beberapa aset kemudian menentukan berapa tingkat aktivitas aktiva-aktiva tesrbut pada tingkat kegiatan tertentu. Aktivitas yang rendah menunjukkan pada tingkat penjualan atau pendapat tertentu akan mengakibatkan semakin besarnya dana kelebihan yang tertanam pada aktiva-aktiva tersebut dan sebaliknya. Analisis yang digunakan adalah Work Capital Turn Over (WCTO) dan Total Assets Turn Over (TAT)

\section{a. Work Capital Turn Over (WCTO)}

Analisis ini digunakan untuk mengukur keefektivan modal kerja dalam menghasilkan penjualan atau pendapatan tertentu. Rasio ini mengukur kefektivan penggunaan modal kerja yaitu aktiva lancar dikurangi dengan hutang lancar dalam menghasilkan penjualan atau pendapatan. Berdasarkan penggunaan rumus tersebut maka diperoleh hasil perhitungan Work Capital Turn Over(WCTO) seperti yang ada pada tabel di bawah ini:

\begin{tabular}{|c|c|c|c|c|c|}
\hline Tahun & Pendapatan & $\begin{array}{c}\text { Aktiva } \\
\text { Lancar }\end{array}$ & $\begin{array}{c}\text { Hutang } \\
\text { Lancar }\end{array}$ & $\begin{array}{c}\text { Modal } \\
\text { Kerja }\end{array}$ & $\begin{array}{c}\text { Perputaran } \\
\text { X }\end{array}$ \\
\hline 2011 & $\mathbf{1 6 . 1 6 6 . 2 6 3}$ & 174.903 .500 & 59.626 .464 & 115.277 .036 & 0,1402 \\
\hline 2012 & $\mathbf{2 5 . 7 3 7 . 3 7 5}$ & 195.003 .500 & 72.055 .352 & 122.948 .148 & 0,2093 \\
\hline 2013 & $\mathbf{2 9 . 8 2 7 . 2 0 8}$ & 206.093 .333 & 67.255 .352 & 138.837 .981 & 0,2148 \\
\hline 2014 & $\mathbf{3 4 . 2 5 2 . 0 0 0}$ & 221.687 .352 & 92.400 .352 & 129.287 .000 & 0,2649 \\
\hline 2015 & $\mathbf{4 0 . 1 5 2 . 0 0 0}$ & 225.987 .352 & 68.200 .352 & 157.787 .000 & 0,2545 \\
\hline
\end{tabular}

Tabel Daftar hasil perhitungan Work Capital Turn Over

\section{b. Total Assets Turn Over(TATO)}

Rasio ini untuk mengukur Rasio ini mengukur perputaran dana yang tertanam dalam aktiva selama periode tertentu yang diinvestasikan untuk menghasilkan pendapatan. Selain itu juga dapat mengukur perputaran aset yang dimilki suatu unit usaha.

\begin{tabular}{|c|c|c|c|}
\hline Tahun & Pendapatan & Total Assets & Ratio \\
\hline 2011 & $\mathbf{1 6 . 1 6 6 . 2 6 3}$ & 155.315 .305 & 0,1041 \\
\hline 2012 & $\mathbf{2 5 . 7 3 7 . 3 7 5}$ & 194.703 .500 & 0,1322 \\
\hline 2013 & $\mathbf{2 9 . 8 2 7 . 2 0 8}$ & 225.693 .333 & 0,1322 \\
\hline 2014 & $\mathbf{3 4 . 2 5 2 . 0 0 0}$ & 241.187 .352 & 0,1420 \\
\hline 2015 & $\mathbf{4 0 . 1 5 2 . 0 0 0}$ & 245.387 .352 & 0,1636 \\
\hline
\end{tabular}

Table daftar hasil perhitungan total Assets Turn Over Tahun 2011-2015

\section{SIMPULAN}

Hasil analisis dan pembahasan yang telah diuraikan maka dapat diambil kesimpulan sebagai berikut:

1. Analisislikuiditaspada koperasi Sinar Harapan dilihatberdasarkan angkarasio yang dihasilkan menunjukkan 
angkayang cukupbaik atau likuid pada analisis Current Ratio yaitu dengan angka sesuai standar (200\%) baik pada tahun 2011-2015 menunjukkan kriteria sangat baik sedangkan pada analisis Cash Ratio menunjukkan hasil yang rata-rata baik sebesar Cash ratio menunjukkan bahwa terjadi penurunan dan peningkatan namun semua itu masih dalam standar. Sehingga menunjukkan kinerja keuangan koperasi Sinar Harapan menunjukkan kemampuan yang baik atau positif untuk membayar hutang.

2. Analisis leverage pada koperasi Sinar Harapan menunjukkan hasil yang sangat baik atau solvable dalam memenuhi kewajiban-kewajiban panjang maupun pendeknya. Hal ini dilihat dari hasil analisis yang menunjukkan sesuai angka yang sesuai standar yang telah ditetapkan. Analisis everage menunjukkan memberikan hasil kinerja keuangan yang positif.

3. Analisis Profibilitas menunjukkan bahwa koperasi Sinar harapan menggunakan analisis ROA (Return on Assets) dan ROE (Return On Equity) menunjukkan bahwa kinerja manajemen koperasi sangat baik dalam menghasilkan SHUyang maksimal. Hal ini dilihat dari angka-angka rasio yang dihasilkan telah sesuai dengan standar yangtelah ditetapkan.

4. Analisis aktivitas menunjukkan tingkat perputaran asset ataupun modal kerja memberikan turn overyang rendah terhadap perolehan pendapatan.

\section{DAFTAR PUSTAKA}

Budi, K Susrusa, Dwi Putra Darmawan. Analisis Kinerja Keuangan pada Koperasi Serba Usaha di Kabupaten Buleleng. Jurnal Manajemen Agribisnis. Vol. 1 No. 2 Oktober 2013

Budiyanto, Albert. Analisis Kinerja Keuangan Koperasi
Karyawan PT XYZ Dengan

Metode Trials. Jurnal Essensi

Vo. 10 No. Tahun 2007. Hal. 23- 42

Departemen Koperasi dan Pembinaan Pengusaha Kecil 1997/1998. Ukuran Keberhasilan Koperasi.

Firdaus, Filjannatul. 2012. "Analisis Rasio Likuditas, Rasio Solvabilitas dan rasio Profitabilitas terhadap Kinerja Keuangan Koperasi As-Sakinah Di Sidoarjo Tahun 2009- 2012”. Retrieved from Ejournal.Unesa.Ac.Id.

IKAPI.1997. Undang-Undang Republik Indonesia No. 25 tahun 1992 Tentang Perkoperasian. Semarang CV. Aneka Ilmu.

Ikatan Akuntan Indonesia. 1998. PSAK Nomor 27 (EdisiRevisi 1998).Jakarta. Salemba Empat. 2002. Standar Akuntansi Keuangan. Jakarta. Salemba Empat. 